\begin{tabular}{|l|l|}
\hline JURNAL ABDI MASYA & Volume 1 No 2 \\
Mei 2021 \\
E-ISSN : 2774-2849 & Pp 103-107 \\
P-ISSN : 2774-2881 & Website : https://jurnal.sttw.ac.id/index.php/abma/about \\
\hline
\end{tabular}

\title{
GERGAJI SELENDANG UNTUK PENGRAJIN MEBEL DI KAMPUNG NGEMPLAK MOJOSONGO SURAKARTA
}

\section{SHAWL SAWS FOR FURNITURE CRAFTSMEN IN VILLAGE NGEMPLAK MOJOSONGO SURAKARTA}

\author{
${ }^{1)}$ Heri Kustanto, ${ }^{2)}$ Tri Rahayu kuat Lestari. \\ 1), Prodi D-3 Teknik Mesin, Sekolah Tinggi Teknologi Warga Surakarta. \\ 2), Prodi D-3 Teknik Elektro, Sekolah Tinggi Teknologi Warga Surakarta. \\ herikustato1@gmail.com
}

\begin{abstract}
ABSTRAK
Pengrajin mebel banyak sekali dijumpai didaerah, dikampung, dipinggir jalan dan pasar mebel diwilayah Surakarta dan sekitarnya, dengan melihat dan memperhatikan para pengrajin mebel tersebut pada saat mengerjakan pekerjaan dengan menggunakan gergaji tangan kecil untuk membuat suatu pola yang berbentuk lengkungan, berbentuk sudut dan tegak lurus dan membutuhkan tenaga cukup banyak, tangan harus bergerak terus naik turunkan gergaji tangan sengkangmya berbentuk huruf C. Salah satu cara yang lebih efektif dan efisien dibuatlah suatu alat atau mesin untuk membantu memecahkan permasalahan yang ada yaitu dengan cara membuat Inovasi mesin gergaji selendang yang mampu mengerjakan bentuk lengkung, bentuk sudut dan juga berbentuk tegak lurus, bilah gergaji berbentuk selendang sehingga gerakannya berputar terus, tidak perlu memakai tangan untuk menggerakkan gergaji, bilah gergaji selendang dilas dipasang pada bantalan yg dihubungkan dengan poros dan poros diputar oleh motor listrik sehingga akan menjadi gerakan berputar,perputan bilah gergaji selendang ini sebagai pengganti gerakan tangan saat naik turun, tangan tinggal menggerakan bahan yang akan dikerjakan atau yang akan dipotong sesuai dengan pola.

Dengan adanya inovasi mesin gergaji selendang tersebut akan dapat membantu proses produksi para pengarajin mebel didaerah Ngemplak Mojosongo khususnya dan Surakarta pada umumnya, hasil produksi lancar, dapat menambah penghasilan dan menambah kesejahteraan kehidupan para pengrajin mebel, dikarenakan produksi bertambah sampai $50 \%$.
\end{abstract}

Kata kunci: gergaji selendang, gergaji tangan, pengrajin mebel

\begin{abstract}
Furniture craftsmen are often found in areas, villages, roadside, and furniture markets in the Surakarta and surrounding areas, by seeing and paying attention to these furniture craftsmen while doing work using a small hand saw to make a pattern that was curved, angular, and perpendicular and requires a lot of energy, the hand must move up and down the hand saw, the blade is in the shape of the letter $C$. One of the more effective and efficient ways to make a tool or machine to help solve existing problems is by making a shawl saw machine innovation that can work on curved shapes, angular shapes, and also perpendicular, shawl-shaped saw blades so that the motion continues, no need to use hands to move the saw, the saw blade is welded on a bearing connected to the shaft and the shaft is rotated by an electric motor so that it will become a rotating motion, twisting the shawl saw blade as a substitute for hand movement when up and down, the hand just moves the material to worked or to be cut according to the pattern.

With the innovation of the shawl saw machine, it will be able to help the production process of furniture craftsmen in the Ngemplak Mojosongo area in particular and Surakarta in general, the results of production are smooth, can increase income, and increase the welfare of the furniture craftsmen's life, because plus $50 \%$ production.
\end{abstract}

Keywords: shawl saws, hand saws, furniture craftsmen

DOI: https://doi.org/10.52561/abma.v1i2.138 


\section{Submit: 21 April 2021 Revision: 20 Mei 2021 Accepted: 24 Mei 2021 \\ Published: 28 Mei 2021}

\section{PENDAHULUAN}

Sentra UKM merupakan wilayah yang bergerak secara bersama-sama menggunakan bahan utama untuk menghasilkan produk yang sejenis maupun berbeda. Sebagai contoh pengrajin mebel, menggunakan bahan kayu untuk membuat berbagai macam mebel, handmade, material bahan bangunan, permainan anak-anak dan lain-lain [1]. Pengrajin mebel banyak tersebar di kota-kota, di desa-desa dan di daerah-daerah, meraka memproduksi antara lain meja, kursi, almari, tempat tidur dan lain-lain. Kendala yang sering dihadapi oleh industry ini adalah pembuatan barang jadi hanya sesuai pesanan, kemampuan tenaga yang kurang, managemen keuangan dan produksi yang belum dikelola dengan baik [2]. Salah satu faktor tingginya biaya produksi adalah karena peralatan yang kurang memadai [3]. Secara umum proses pembuatan mebel meliputi, persiapan alat dan bahan, pemotongan bahan sesuai ukuran, perakitan bahan, dan finishing. Permasalahan pada proses pemotongan adalah saat proses pembuatan lengkung atau berbentuk profil bulat atau lonjong dan sudut masih menggunakan gergaji tangan. Tingkat kesulitan pada saat proses pengerjaan, tangan kanan menggerakkan gergaji naik turun dan tangan kiri menggerakkan papan yang dipotong. Hasil kurang bagus dan memakan waktu cukup lama sehingga produksi kurang lancar. Untuk memperlancar hasil produksi dengan cara membuat inovasi atau rancang bangun berupa pembuatan mesin gergaji selendang untuk memotong berbentuk bulat atau oval maupun bersudut. Metodenya adalah bilah gergaji bentuk selendang dilas atau disambung, jadikan dua bantalan untuk meletakkan bilah gergaji satu pada bantalan atas dan satu bantalan bawah. Bantalan atas diputar oleh motor listrik sebagai pengganti tangan pada saat gerakan naik turun. Sehingga bilah gergaji dapat bergerak turun untuk memotong tanpa menggunakan tangan untuk menggerakkan bilah gergji. tangan digunakan untuk menggerakkan benda kerja sesuai dengan pola yang ada.

Kelemahan untuk para pengrajin mebel secara umum adalah sebagai berikut : kurangnya keahlian / skill para pengrajin mebel, kurangnya motivasi diri dari para pengrajin mebel, tidak adanya pendampingan dan pembinaan dari pihak lain sehingga menyebabkan mereka tidak tahu apa yang harus mereka lakukan dan kerjakan untuk meningkatkan produksi mebel, sehingga dapat menyongsong masa depannya yang lebih baik. Menurut Irfan [4] salah satu metode yang dilakukan aadalah metode pendampingan, dengan maksud untuk evaluasi setelah pelatihan, mengecek pekerjaan dan melakukan bimbingan. Menurut Nursalim [5] metode untuk meningkatkan kualitas dan mempercepat proses produksi UKM mebeler adalah dengan mekanisasi yaitu pembaruan mesin produksi, pendampingan dan monitoring penerapan mesin.

Dengan adanya inovasi mesin gergaji selendang tersebut diharapkan menghemat waktu proses produksi, menambah kualitas pekerjaan dan menambah kuantitas produksi. Kuantitas produksi meningkat, sehingga menambah penghasilan para pengrajin mebel tersebut dan menambah kesejahteraan para pengrajin mebel.

\section{METODE}

Pelaksanaan program Iptek bagi Masyarakat (IbM) ini diawali dengan mengadakan survey dirumah Bapak Rudhi Hartono (42 Tahun) kampung Ngemplak kalurahan Mojosongo Kecamatan Jebres Surakarta Jawa Tengah. Langkah berikutnya adalah pembuatan dan penggunaan mesin gergaji selendang. Mesin gergaji selendang diserahkan ke UKM dengan terlebih dahulu dilakukan pelatihan operasional alat dan perawatannya.

Sebelum melaksanaan Pengabdian Pada Masyarakat / Iptex bagi Masyarakat ini perlu adanya skema atau alur-alur sebelum pelaksanaan dimulai, dibawah ini gambar 1 alur pelaksanaan IbM.

DOI: $\underline{\text { https://doi.org/10.52561/abma.v1i2.138 }}$ 


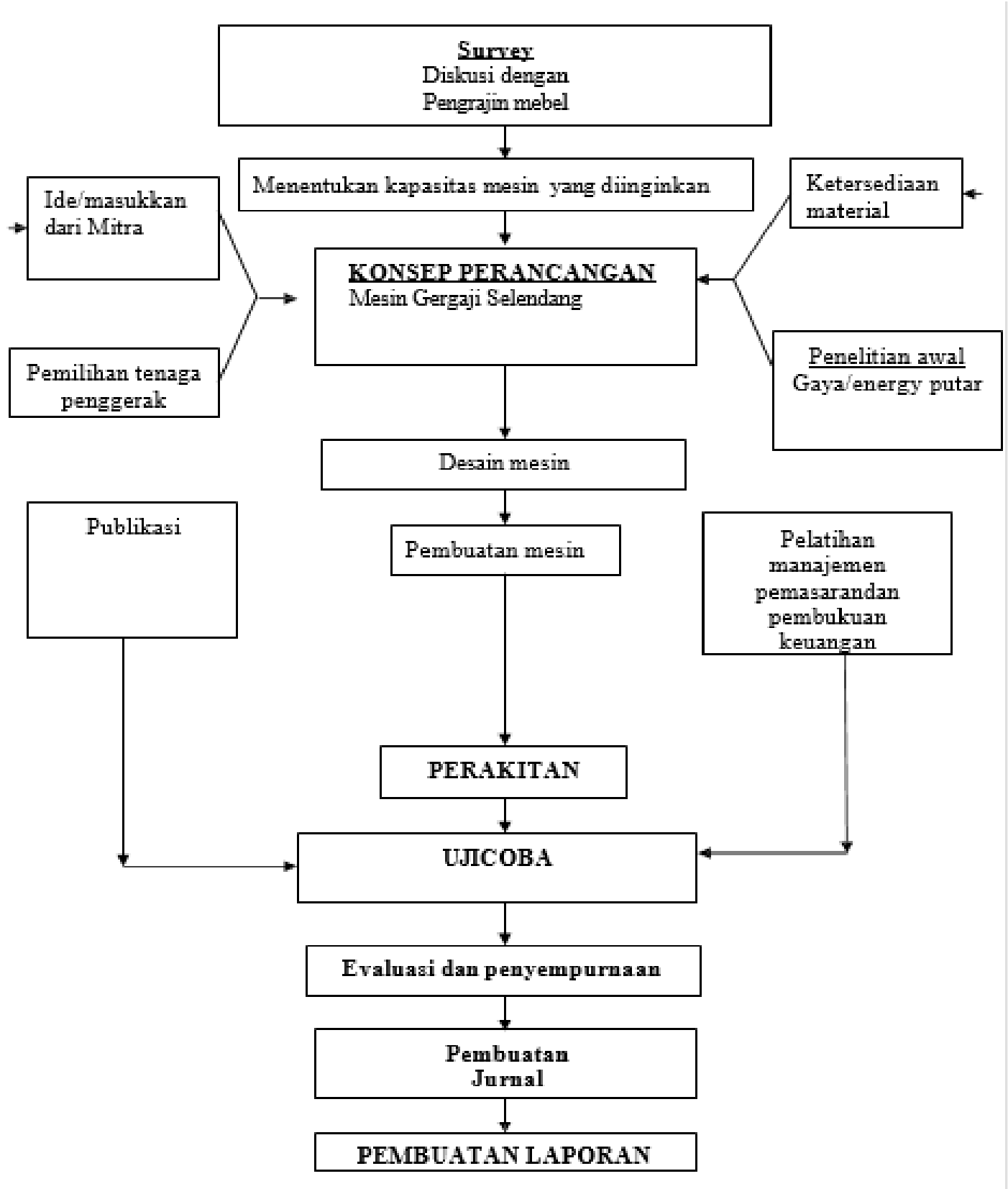

Gambar 1 Diagram Alur Pelaksanaan IbM

\section{HASIL DAN PEMBAHASAN}

Pelaksanaan salah satu Tri Dharma Perguruan Tinggi adalah mengadakan Pengabdian Pada Masyarakat, melaksanakan program Iptek bagi Masyarakat (IbM) dengan judul gergaji selendang untuk pengrajin mebel di kampung Mojosongo Jebres Surakarta. Hasil berupa gergaji selendang dengan spesifikasi motor 1 phase 220, volt 1,2 Ampere, frekvensi $50 \mathrm{~Hz}$, putaran $1400 \mathrm{rpm}$, lebar gergaji $1 \frac{2}{2}$ inchi. Aplikasi alat sangat dirasakan oleh pihak UKM dengan uicoba untuk membuat pola atau sudut. Pembuatan pola dengan manual rata-rata menghasilkan 3 pola per hari, sedangkan setelah 
menggunakan mesin gergaji selendang dapat menghasilkan 6 pola. Sehingga dengan adanya msin ini meningkatkan produksi sebesar 50\%. Kemampuan mesin gergaji selendang dapat digunakan pada kayu dengan ketebalan bahan $3 \mathrm{~cm}$.

Hasil rekayasa / inovasi mesin gergaji selendang dapat dilihat pada gambar 2. dibawah ini.

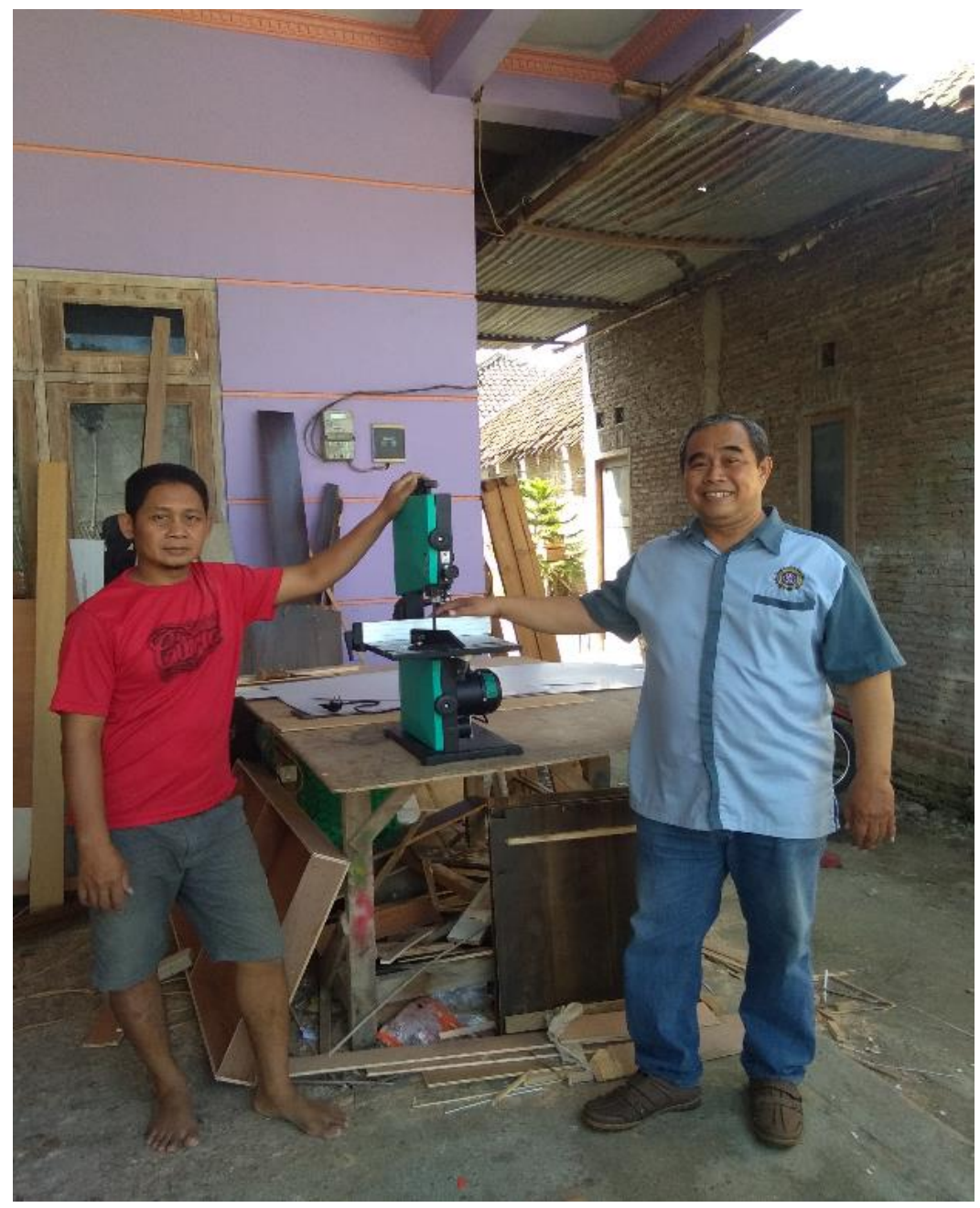

Gambar 2. Gergaji selendang bersama mitra dan pelaksana IbM

\section{KESIMPULAN}

Pengabdian pada masyarakat ini menghasilkan produk berupa mesin gergaji selendang dengan penggerak motor listrik 1 phase. Kapasitas produksi meningkat 50\% dibanding secara manual.

\section{UCAPAN TERIMA KASIH}

Kepada bapak Rudy Hartono yang mau meluangkan waktu dan tenaganya serta tempat tinggalnya untuk ujicoba gergaji selendang serta masyarakat pengrajin mebel sekitarnya dan juga masyarakat kampung Ngemplak Mojosongo Surakarta yang juga selalu mengikuti dan memperhatikan pada saat ujicoba gergaji selendang tersebut sampai selesai. 


\section{DAFTAR PUSTAKA}

[1] Sofiana, Yunida. "Analisis Strategi Peningkatan Produksi Mebel di Sentra Industri Kayu." Humaniora 2, no. 1 (2011): 1-10.

[2] Koswara, Aji. "Model Pelatihan Peningkatan Keterampilan Teknis Bermuatan NilaiNilai Estetis Bagi Perajin Mebel Kayu Dalam Perspektif Pendidikan Orang Dewasa." PhD diss., Universitas Pendidikan Indonesia, 2012.

[3] Mellolo, Ottopianus, Maureen Langie, and Eliezer M. Rongre. "IPTEKS Bagi Pengrajin Mebel Usaha Kecil Guna Meningkatkan Keterampilan Dan Hasil Produksi." Prosiding Semnas Hasil Pengabdian Masyarakat (2016).

[4] Irfan, Irfan, Ali Ahmad Muhdy, and Hamrin Hamrin. "Penerapan Identitas Lokal pada Mebel Kayu melalui Pelatihan dan Pendampingan." Jurnal Imajinasi 3, no. 2 (2019): 67-74.

[5] Nursalim, Nursalim, Agusthinus S. Sampeallo, Abdul Wahid, and Nixson J. Meok. "Upaya Peningkatan Produksi Mebel Pada Umkm Kota Kupang Berbasis Teknologi Tepat Guna." Dinamisia: Jurnal Pengabdian Kepada Masyarakat 3, no. 2 (2019): 258265. 